\title{
Introduction to the new special issue for the 2018 SOMIB / CNIB
}

\section{Luis Kun ${ }^{1}$}

(C) IUPESM and Springer-Verlag GmbH Germany, part of Springer Nature 2020

The Mexican Society of Biomedical Engineering (in Spanish: Sociedad Mexicana de Ingeniería Biomédica, SOMIB) held its 2018 National Congress in Biomedical Engineering (in Spanish: Congreso Nacional de Ingeniería Biomédica, CNIB) annual meeting in the city of León de Guanajuato, Mexico while celebrating its 41st anniversary.

The meeting attracted thousands of participants (see picture below) and was a complete success. As the meeting was being planned, I invited Dr. Dora-Luz Flores and Dr. Nelly Gordillo-Castillo to be Co-Guest Editors of a Special Issue for our Journal. Towards the end of the meeting we held a special: "Meet the Editors" session where the three of us met with hundreds of interested individuals in participating. Many of the details regarding writing, submitting, reviewing, editing, the peer-review process, etc. were discussed.

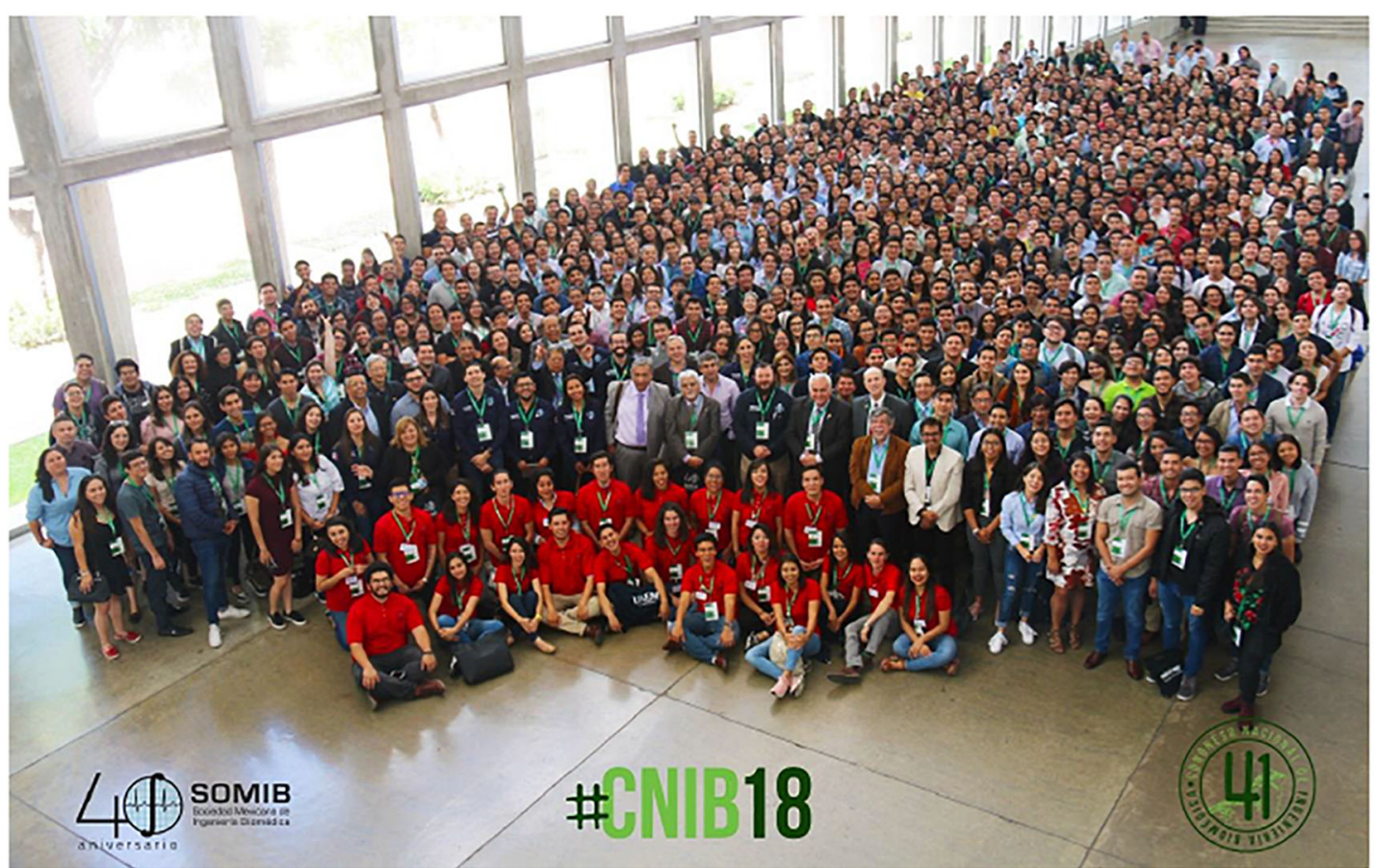

Picture 1. Many of the participants of the 2018 SOMIB / CNIB in Leon, Mexico. Dr. Nelly Gordillo-Castillo, and Dr. Dora-Luz Flores were the Guest Editors of a Special Issue of the Journal Health \& Technology dedicated to papers presented last year at the 2018 National Congress in Biomedical Engineering (CNIB) of the Mexican Society of Biomedical Engineering (SOMIB) that took place in the city of Leon on October 2018

Luis Kun

hcii@aol.com

1 (Former) W. Perry, Center for Hemispheric Defense Studies at National Defense University, Washington, DC, USA 
Paper Títle

An index to prioritize the preventive maintenance of medical equipment [1]

Galloping gait analysis of a beetle from the Scarabaeidae family [2]

Development of a Haptic System for Occupational Hand Therapy [3]

Design of a Haptic System for Medical Image Manipulation Using Augmented Reality [4]

Development of a Virtual Reality Application for Interactive Visualization of Respiratory Sounds Signals [5]

Mapping the friction coefficient of AISI 316 L on UHMWPE lubricated with bovine serum to study the effect of loading and entrainment at high values of sliding-to-rolling ratio [6]

Effect of cell size on insulin secretion in human $\beta$-cells: a simulation study [7]

Automated extraction of fine and coarse crackles by Independent Component Analysis [8]

Developing a visual perimetry test based on eye-tracking: proof of concept [9]

Multimodal 3D Rigid Image Registration based on Expectation Maximization [10]

Implementing air flow sensor in a medical mask for breathing detection [11]

Design of an electronic prototype to teach braille [12]

Analysis of vibrational modes from alpha-synuclein: a theoretical model using density functional theory and Raman spectroscopy [13]

Assistant Computer Program for Adequate Disposal of Medical Devices [14]

Characterization and Hemocompatibility Assessment of Porous Composite Scaffolds with a Biomimetic Human Clavicle Macrostructure [15]

Development and implementation of algorithms with diffusion tensor images to evaluate brain connectivity [16]

RFID + Wi-Fi system to control the location of biomedical equipment within hospital areas and linked to an intelligent inventory [17]
Authors

Hernández-López, L.A., Pimentel-Aguilar, A.B. \& Ortiz-Posadas

Romo Rivera, E., Anzueto Ríos, A. \& Colin Romero, B.J.

Ovando-Becerril, E.D., Salazar-Medrano, M.G., Robles-Mendoza, A.G. et al.

Hernández-Sierra, L.J., Mendoza-Gutiérrez, M.O. \& Mejía-Rodríguez, A.R.

Castillo-Gonzalez, R., Cerda-Davila, D.A., Charleston-Villalobos, S. et al.

Montes-Seguedo, J.L., Garcia-Garcia, A.L., Barceinas-Sanchez, J.D.O. et al.

Félix-Martínez, G.J., Godínez-Fernández, J.R.

García, M.E.R., Villalobos, S.C., Villa, N.C. et al.

Martínez-González, E.A., Alba, A., Méndez, M.O. et al.

Velázquez-Durán, M.J., Campos-Delgado, D.U., Arce-Santana, E.R. et al.

Rangel, D., Castillo, D.D.C.

Peñaloza-Mendoza, G.R., Sánchez-Rodríguez, A.A., Melgoza-Rivera, P.Y. et al.

León-Bejarano, F., Ramírez-Elías, M.G., Méndez, M.O. et al.

Reyes-Soto, C.E., Ledesma-Ramírez, C.I. \& Pliego-Carrillo, A.C.

Chi Perera, C., Castillo Baas, M., Alcocer Lara, G. et al.

Hernandez, N.R., Montelongo, R.H., Bernal, .M.C. et al.

Salinas Gómez, F., Suárez Escobar, N.E. \& Vázquez, J.
After a selection process, 17 papers were among the finalists. The following authors are introduced here with the titles of their respective articles. These submitted articles were accepted after peer-review and are part of this Special Issue.

Picture 2.- Dr. Dora-Luz Flores

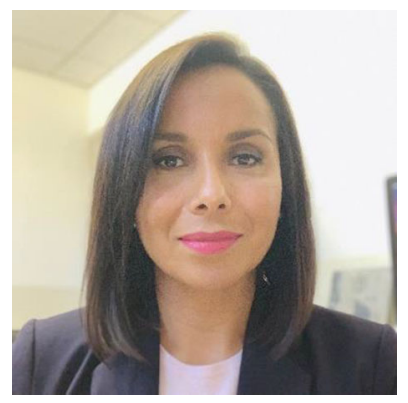

\section{Picture 3.- Dr. Nelly Gordillo-Castillo}

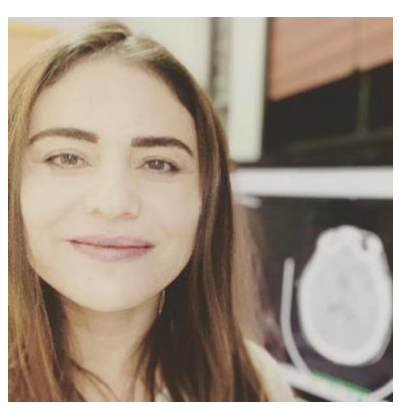

I would like to thank both Dr. Flores and Dr. Gordillo-Castillo for their effort in putting together this Special Issue, making sure in addition to the peer-review, that all papers were accurate and well translated. 
NOTE: On October 4, 2019, during my talk ${ }^{1}$ at the Latin American Congress in Biomedical Engineering (in Spanish Congreso Latino Americano de Ingeniería Biomédica, CLAIB 2019) in Cancún, México it was announced that all the papers of this Special Issue were available for free downloads for a period of one month at the Springer's website.

Best wishes to all.

Luis Kun, Ph.D., Fellow AIMBE, Life Fellow IEEE, Fellow IAMBE Editor in Chief - Journal of Health \& Technology Springer - IUPESM - WHO.

\section{Compliance with ethical standards}

Conflict of interest The authors declare that they have no conflict of interest.

\section{References}

1. Hernández-López LA, Pimentel-Aguilar AB, Ortiz-Posadas MR. An index to prioritize the preventive maintenance of medical equipment. Health Technol. 2019:1-5. https://doi.org/10.1007/s12553019-00371-y.

2. Romo Rivera E, Anzueto Ríos A, Colin Romero BJ. Galloping gait analysis of a beetle from the Scarabaeidae family. Health Technol. 2019:1-6. https://doi.org/10.1007/s12553-019-00351-2.

3. Ovando-Becerril ED, Salazar-Medrano MG, Robles-Mendoza AG, Mendoza-Gutiérrez MO, Bonilla-Gutiérrez I. Development of a haptic system for occupational hand therapy. Health Technol. 2019:1-7. https://doi.org/10.1007/s12553-019-00352-1.

4. Hernández-Sierra LJ, Mendoza-Gutiérrez MO, Mejía-Rodríguez AR. Design of a haptic system for medical image manipulation using augmented reality. Health Technol. 2019:1-5. https://doi. org/10.1007/s12553-019-00372-x.

5. Castillo-Gonzalez R, Cerda-Davila DA, Charleston-Villalobos S, Aljama-Corrales AT, Reyes BA. Development of a virtual reality application for interactive visualization of respiratory sounds signals. Health Technol. 2019:1-5. https://doi.org/10.1007/s12553019-00364-x.

6. Montes-Seguedo JL, Garcia-Garcia AL, Barceinas-Sanchez JDO, Sosa-Savedra JC, Morales-Garcia MRJ, Gonzalez-Jasso E, et al. Mapping the friction coefficient of AISI 316L on UHMWPE lubricated with bovine serum to study the effect of loading and entrainment at high values of sliding-to-rolling ratio. Health Technol. 2019:1-6. https://doi.org/10.1007/s12553-019-00355-y.

7. Félix-Martínez GJ, Godínez-Fernández JR. Effect of cell size on insulin secretion in human $\beta$-cells: a simulation study. Health Technol. 2019:1-5. https://doi.org/10.1007/s12553-019-00350-3.

8. García MER, Villalobos SC, Villa NC, González AJ, Camarena RG, Corrales TA. Automated extraction of fine and coarse crackles by independent component analysis. Health Technol. 2019:1-5. https://doi.org/10.1007/s12553-019-00365-w.

9. Martínez-González EA, Alba A, Méndez MO, Fernández-Wong J. Developing a visual perimetry test based on eye-tracking: proof of concept. Health Technol. 2019:1-5. https://doi.org/10.1007/ s12553-019-00366-9.

10. Velázquez-Durán MJ, Campos-Delgado DU, Arce-Santana ER, Mejía-Rodríguez AR. Multimodal 3D rigid image registration based on expectation maximization. Health Technol. 2019:1-7. https://doi.org/10.1007/s12553-019-00353-0.

11. Rangel D, Castillo DDC. Implementing air flow sensor in a medical mask for breathing detection. Health Technol. 2019:1-6. https://doi. org/10.1007/s12553-019-00356-x.

12. Peñaloza-Mendoza GR, Sánchez-Rodríguez AA, Melgoza-Rivera PY, Espinosa-Hurtado S. Design of an electronic prototype to teach braille. Health Technol. 2019:1-6. https://doi.org/10.1007/s12553019-00373-w.

13. León-Bejarano F, Ramírez-Elías MG, Méndez MO, Guirado-López RA, Alba A, Rodríguez-Leyva I. Analysis of vibrational modes from alpha-synuclein: a theoretical model using density functional theory and Raman spectroscopy. Health Technol. 2019:1-6. https:// doi.org/10.1007/s12553-019-00367-8.

14. Reyes-Soto CE, Ledesma-Ramírez CI, Pliego-Carrillo AC. Assistant computer program for adequate disposal of medical devices. Health Technol. 2019:1-3. https://doi.org/10.1007/s12553019-00368-7.

15. Chi Perera C, Castillo Baas M, Alcocer Lara G, et al. Characterization and hemocompatibility assessment of porous composite scaffolds with a biomimetic human clavicle macrostructure. Health Technol. 2019:1-6. https://doi.org/10.1007/s12553019-00374-9.

16. Hernandez NR, Montelongo RH, Bernal JMC, González JRO. Development and implementation of algorithms with diffusion tensor images to evaluate brain connectivity. Health Technol. 2019:18. https://doi.org/10.1007/s12553-019-00376-7.

17. Salinas Gómez F, Suárez Escobar NE, Vázquez J. RFID + Wi-fi system to control the location of biomedical equipment within hospital areas and linked to an intelligent inventory. Health Technol. 2019:1-5. https://doi.org/10.1007/s12553-019-00393-6.

Publisher's note Springer Nature remains neutral with regard to jurisdictional claims in published maps and institutional affiliations.

\footnotetext{
${ }^{1}$ Invited Keynote: Wellness Transformation Through Disease Prevention: Genetics, Geomedicine, Information Sharing \& Interoperability, at CLAIB 2019, the VIII Latin American Congress in Biomedical Engineering, October 4, 2019. Cancún, México. (http://claib.org/ing/docs/LUIS_KUN.pdf)
} 